\title{
RECHTSREGEL
}

Jurnal Ilmu Hukum Vol 1, No 1 Agustus 2018

P-ISSN 2622-6235, E-ISSN 2622-6243,

\section{PERLINDUNGAN HAK TERSANGKA DARI KETERANGAN SAKSI YANG TIDAK DAPAT DIPERCAYA}

\author{
Hendrik F Siregar \\ Fakultas Huku, Universitas Pamulang \\ Email : hendrik_fs@yahoo.com
}

Received: - /Revised: - /Accepted: Ags 2018

\begin{abstract}
Perlindungan Hukum kepada terdakwa adalah upaya atau bentuk layanan yang diberikan oleh hukum kepada terdakwa serta materi hukum ke objek yang dilindungi, termasuk perlindungan terdakwa dari saksi yang tidak dapat dipercaya. Ketentuan pasal 185 ayat 6 huruf (d) KUHAP telah memberikan perlindungan hukum kepada terdakwa dalam kaitannya dengan saksi yang tidak dapat dipercaya, pasal 185 ayat 6 huruf (d) KUHP berfungsi sebagai mercusuar dalam peringatan hakim untuk memperhatikan kesaksian dengan bebas, jujur dan obyektif.
\end{abstract}

Kata Kunci : Perlindungan Hukum, Layanan Hukum, Hukum Pidana

\section{ABSTRACT}

Legal Protection to the accused is an attempt or a form of service granted by law to the defendant as well as the legal subject matters into the protected object, including the protection of the defendant from the witness who can not be trusted.The provisions of article 185 paragraph 6 letter (d) Criminal Procedure Code (KUHAP) has been providing legal protection to the defendant in relation to the witness who can not be trusted, article 185 paragraph 6 letter (d) Criminal Code has a function as a lighthouse in alerting the judge to pay attention to the testimony freely,honestly and objectively.

Keywords: Legal Protection, Legal Services, Criminal Law 


\section{PENDAHULUAN}

Ibu Khaldun mengatakan manusia adalah mahluk yang tergantung pada tabiat, sedangkan Murtadha Muthahari menjelaskan manusia adalah mahluk yang paradoksal pada dirinya terdapat sifat-sifat baik dan jahat sekaligus, tetapi sifatsifat tersebut hanyalah hal-hal yang bersifat potensial. ${ }^{1}$

Merujuk pendapat dua ahli di atas seorang saksi adalah manusia biasa yang selalu berada dalam situasi moral atau cara hidup tertentu, seperti dengan sengaja dapat berbohong, dan dapat juga jujur menceritakan sesuatu hal, seorang saksi dimungkinkan memberikan keterangan seolah-olah yang disampaikan adalah fakta yang benar, akan tetapi sebetulnya keterangan tersebut tidak benar, bahkan dapat terjadi seorang saksi memiliki situasi emosi tertentu pada terdakwa, dan dimungkinkan pula seorang saksi harus menceritakan fakta yang sudah lampau dan keadaan dan situsi ini sangat tergantung daya ingat dari orang perseorang.

Selama ini pengertian saksi dapat di pahami sebagai orang yang dapat memberikan keterangan guna kepentingan penyidikan, penuntutan dan peradilan tentang suatu perkara pidana yang ia dengar sendiri, ia lihat sendiri, dan ia alami sendiri, sebagaimana dimaksud dalam pasal 1 angka 26 KUHAP.

Menurut ketentuan pasal 184 huruf (a) KUHAP keterangan saksi berlaku sebagai alat bukti yang sah dalam perkara pidana yang berupa keterangan mengenai suatu peristiwa pidana yang ia dengar sendiri, ia lihat sendiri, dan ia alami sendiri dengan

.Murtadha Muthahari , Perspektif al-Quran tentang manusia dan
Agama.Mizan,Bandung,1998,hlm.123 
menyebut alasan berdasarkan pengetahuanya (pasal 1 butir 27 KUHAP)2

Merujuk ketentuan pasal 184 huruf (a) KUHAP di atas keterangan seorang saksi sangat menentukan apakah terdakwa bersalah ataukah tidak sehubungan dengan tindak pidana yang dituduhkan padanya, sehingga latar belakang kesusilaan/moralitas dan cara hidup seorang saksi memiliki pengaruh terhadap keterangan yang nantinya akan diberikan di depan persidangan, seorang saksi yang memiliki latar belakang kesusilaan dan cara hidup yang tidak baik dikhwatirkan akan memberikan kesaksian yang jauh dari kebenaran yang pada akhirnya keterangan tersebut merugikan hak terdakwa dalam mendapatkan keadilan dan kepastian hukum, padahal hak terdakwa untuk mendapatkan peradilan yang adil dan patut menurut hukum telah diatur dalam Undang-undang Republik Indonesia No.48 Tahun 2009 Tentang Kekuasaan Kehakiman, dalam Pasal 6 ayat (2) yang pada intinya menyatakan tidak seorangpun dijatuhi pidana kecuali apabila pengadilan karena alat pembuktian yang sah menurut undangundang dan hakim telah meyakini seseorang yang dianggap dapat bertanggungjawab, telah bersalah atas perbuatan yang didakwakan atas dirinya.

Keterangan Seorang saksi sebagai alat bukti yang sah dan sebagai salah satu dasar hakim memutuskan terdakwa bersalah diatur pula dalam Pasal 6 ayat (2) Undang-undang Republik Indonesia No.48 Tahun 2009 Tentang Kekuasaan Kehakiman, disebutkan alat bukti merupakan dasar bagi hakim untuk menjatuhkan putusan terdakwa bersalah ataupun tidak bersalah.

${ }^{2}$ Kuffal, HMA. Penerapan KUHAP dalam praktik Hukum, UMM Press, Malang, 2011, hlm. 175 . 
Menurut Penulis alat bukti yang dimaksud dalam Pasal 6 ayat (2) Undang-undang Republik Indonesia No.48 Tahun 2009 Tentang Kekuasaan Kehakiman apabila dihubungan dengan Kitab Undangundang Hukum Acara Pidana (KUHAP) adalah keterangan seorang saksi (pertama yang disebut dalam KUHAP) dan pada umumnya tidak ada perkara pidana yang luput dari pembuktian alat bukti keterangan saksi karena hampir semua pembuktian perkara pidana selalu bersandar kepada pemeriksaan keterangan saksi sekurang-kurangnya disamping pembuktian dengan alat bukti yang lain.

Mengingat pentingnya keterangan seorang saksi dalam pembuktian maka hakim dalam menilai kebenaran/masuk akal/kejujuran keterangan seorang saksi, hendaknya memperhatikan Cara hidup dan kesusilaan saksi dan segala sesuatu yang pada umumnya dapat mempengaruhi dapat tidaknya keterangan saksi tersebut dapat dipercaya.

Penilaian hakim terhadap kebenaran / masuk akal/ kejujuran keterangan seorang saksi dapat dilihat dalam Pasal 185 ayat 6 huruf (d) KUHAP yang menegaskan hakim dalam menilai kebenaran keterangan seorang saksi, harus dengan sungguhsungguh memperhatikan Cara hidup dan kesusilaan saksi dan segala sesuatu yang pada umumnya dapat mempengaruhi dapat tidaknya keterangan itu dipercaya.

Rumusan Pasal 185 KUHAP ayat (6) huruf (d) memberikan Patokan/rambu pada hakim agar memperhatikan kesusilaan dan cara hidup saksi pada saat seorang saksi memberikan keterangan tentang apa yang saksi lihat/ saksikan, saksi dengar dan ketahui tentang suatu fakta didepan persidangan agar nantinya hakim dapat memberikan putusan yang adil bagi terdakwa. Cara hidup 
dan kesusilaan seorang saksi merupakan persoalan moralitas, hal berarti mengharuskan hakim masuk dalam Penilaian Baik dan buruknya cara hidup dan kesusilaan saksi pada saat hakim menilai kebenaran isi keterangan saksi, sedangkan istilah moral berasal dari kata latin : moralis, dan istilah ethic berasal dari bahasa Yunani: ethos. Keduanya berarti "kebiasaan atau cara hidup".3 Seorang hakim hendaknya tidak hanya menggali dan menilai isi atau muatan keterangan seorang saksi didepan persidangan saja, tetapi lebih jauh hakim seharusnya menilai motif/latar belakang ketika seorang saksi memberikan keterangan demikian Sebagaimana diamanatkan dalam Pasal 185 huruf ayat 6 huruf (d) KUHAP, Pasal 184 KUHAP dan Undang-undang Republik Indonesia No.48 Tahun 2009 Pasal 6 ayat (2).

Faktanya hakim dalam memeriksa dan menilai keterangan saksi dimungkinkan mengabaikan Pasal 185 huruf ayat 6 huruf (d) KUHAP hal ini disebabkan karena beberapa alasan, diantaranya banyaknya perkara yang ditangani seorang hakim sehingga hanya berpedoman pada BAP (berita acara Pemeriksaan) dan berkas perkara saja dalam pemeriksaan saksi, dan hakim malas untuk menggali lebih jauh pada kedalaman pribadi seorang saksi yang pada akhirnya putusan tersebut akan mencederai rasa keadilan dan kepastian hukum serta akan menghasilkan peradilan yang sesat.

Dalam suatu pemeriksaan di persidangan hakim dihadapkan pada keterangan seorang saksi di depan persidangan menyatakan bahwa dia telah terbiasa melakukan perdukunan uang, menggandakan mata uang dan seterusnya, padahal

3 Titus et.al, Persoalan-persoalan Filsafat,Terjemahan, H.M.Rasjidi, Bulan Bintang, Jakarta,1984, Hal.140. 
dimanapun semua orang pasti tahu perbuatan tersebut menyesatkan dan jelas merupakan penipuan dan menyatakan memiliki kemampuan untuk melakukan penarikan uang seseorang yang dipinjam oleh orang lain secara gaib dengan melalui ritual tertentu, padahal Kemampuan untuk mendatangkan uang secara gaib berada pada areal diluar jangkauan panca indra manusia dan tidak dapat diterima oleh akal sehat, disisi lain hakim dihadapkan pada seorang saksi yang memiliki cara hidup dan kesusilaan yang tidak baik yaitu suka membeli minuman keras dengan uang yang bukan miliknya dan memiliki kebiasaan yang suka meminum minuman keras. Terhadap saksi-saksi di atas maka seorang hakim hendaknya tidak hanya menggali dan menilai isi atau muatan keterangan saksi tersebut, tetapi lebih jauh hakim seharusnya menilai motif/latar belakang ketika seorang saksi memberikan keterangan demikian.

\section{PERMASALAHAN}

Apakah penerapan Pasal 185 huruf ayat 6 huruf (d) KUHAP telah memberikan perlindungan pada terdakwa dalam kaitanya dengan keterangan saksi yang tidak dapat dipercaya dan bagaimana upaya yang dilakukan hakim untuk melindungi hak terdakwa?

\section{PEMBAHASAN}

\section{Negara dan Perlindungan Hak Asasi Terdakwa}

Indonesia Sebagai Negara Hukum (Rechtstaat dan "Rule of The Law") merumuskan prinsip perlindungan hukum bagi warga Negara adalah prinsip pengakuan dan perlindungan terhadap harkat dan martabat manusia yang bersumber pada Pancasila, 
sebagai ideologi dan falsafah negara Pancasila merupakan landasan Dalam merumuskan prinsip-prinsip perlindungan hukum di Indonesia.

Dalam Negara hukum (Rechtstaat) Setiap warga negara memiliki kedudukan yang sama di hadapan hukum dan dimuka sidang pengadilan. Prinsip ini sesuai dengan prinsip negara hukum, dimuka hukum setiap orang akan mendapatkan perlakuan yang sama, tak ada satupun yang mempunyai kekebalan dan keistimewaan terhadap hukum. Apabila prinsip ini benar-benar terwujud, masyarakat akan merasa tentram dalam pengayoman hukum yang berlaku. ${ }^{4}$

Kedudukan yang sama warga negara di hadapan hukum tercantum pada Pasal 27 ayat (1) undang-undang Dasar 1945 yang berbunyi :

“ segala warga negara bersama kedudukanya di dalam hukum dan pemerintahan dan wajib menjunjung hukum dan pemerintahan itu dengan tidak ada kecualinya”.

Sedangkan Kedudukan yang sama warga negara dimuka sidang pengadilan dituangkan dan diatur dalam undang-undang No. 4 tahun 2004 jo. Undang-undang No 48 Tahun 2009 tentang ketentuan ketentuan pokok kekuasaan kehakiman atau Undangundang kekuasaan kehakiman, akan tetapi baru setelah sebelas tahun kemudian asas-asas tersebut dapat dituangkan dalam KUHAP dan dijabarkan menjadi 10 (sepuluh) asas sebagai berikut:

1) Perlakuan yang sama atas diri setiap orang di muka hukum dengan tidak mengadakan perbedaan perlakukan;

${ }^{4}$ Soche, Harris. Supremasi hukum dan prinsip demokrasi di Indonesia, Pt.Hanindita, Jogjakarta, 1985, hal.37. 
2) Penangkapan, penahanan, penggeledahan dan penyitaan hanya dilakukan berdasarkan perintah tertulis oleh pejabat yang diberi wewenang oleh undang-undang;

3) Setiap orang yang disangka, ditangkap, ditahan, dituntut, dan atau dihadapkan di muka sidang pengadilan, wajib dianggap tidak bersalah sampai adanya putusan pengadilan yang menyatakan kesalahannya dan memperoleh kekuatan hukum tetap (Presumption of innoncence);

4) Kepada seseorang yang ditangkap, ditahan, dituntut, ataupun diadili tanpa alasan yang bedasarkan undang-undang dan atau karena kekeliruan mengenai orangnya, atau hukum yang diterapkan wajib diberi ganti kerugian dan rehabilitasi sejak tingkat penyidikan dan para pejabat penegak hukum yang dengan sengaja atau karena kelalaianya menyebabkan asas hukum tersebut dilanggar, dituntut, dipidana dan atau dikenakan hukuman administrasi;

5) Peradilan yang harus dilakukan dengan cepat, sederhana dan biaya ringan serta bebas, jujur dan tidak memihak harus diterapkan secara konsekwen dalam seluruh tingkat peradilan;

6) Setiap orang yang tersangkut perkara wajib diberi kesempatan memperoleh bantuan hukum yang semata-mata diberikan untuk melaksanakan kepentingan pembelaan atas dirinya;

7) Kepada seorang tersangka, sejak saat dilakukan penangkapan dan atau penahanan selain wajib diberitahu dakwaan dan dasar hukum apa yang didakwakan kepadanya, juga wajib diberikan haknya itu termasuk hak untuk menghubungi dan meminta bantuan penasihat hukum;

8) Pengadilan memeriksa perkara pidana dengan hadirnya terdakwa; 
9) Sidang pemeriksaan pengadilan adalah terbuka untuk umum kecuali dalam hal yang diatur dalam undang-undang;

10)Pengawasan pelaksanaan putusan pengadilan dalam perkara pidana dilakukan oleh Ketua Pengadilan Negeri yang bersangkutan. ${ }^{5}$

Asas praduga tidak bersalah (Presumption of innoncence) merupakan suatu perwujudan dari penerapan proses hukum yang adil (due procees) dan pelaksanaan dari hak asasi manusia. Salah satu hak terdakwa sebagai subjek hukum bila dikaitkan dengan perlindungan hukum terdakwa dari keterangan saksi yang tidak dapat dipercaya adalah hak terdakwa untuk dapat diproses secara layak (right of fair hearing). Hak ini merupakan penjabaran dari asas Praduga tak bersalah (presumption of innoncence). Dokrin praduga tidak bersalah ini adalah merupakan suatu perwujudan dari penerapan proses hukum yang adil (due procees) dan pelaksanaan dari hak asasi manusia serta pelaksanaan prinsipprinsip hukum alam. ${ }^{6}$

Prinsip hukum alam merupakan ketetapan Tuhan, prinsipprinsip hukum alam merupakan prinsip yang berlaku untuk semua proses kehidupan, keseimbangan merupakan bagian dari hukum alam, karena di dalam keseimbangan terdapat potensi/kekuatan untuk mencapai keadilan.

Dalam Proses peradilan pidana prinsip-prinsip keseimbangan dalam hukum alam merupakan prinsip yang juga berlaku pada diri seorang hakim yaitu karena di dalam

5 Kuffal, HMA. Penerapan KUHAP dalam Praktek Hukum, UMM Press, Malang, 2011, hal.132.

6 Fuady,Munir dan Sylvia Laura L.Fuady, Hak Asasi Tersangka Pidana, Prenada Media Group, 2015, hal.210. 
keseimbangan terdapat potensi/kekuatan untuk mencapai keadilan.

Dalam diri hakim diemban suatu amanah agar peraturan perundang-undangan diterapkan secara benar dan adil, dan apabila penerapan peraturan perundang-undangan akan menimbulkan ketidakadilan, maka hakim wajib berpihak pada keadilan Moral (moral Justice) dan mengeyampingkan hukum atau peraturan perundang-undangan (Legal Justice). ${ }^{7}$

Hakim akan dihargai dan memiliki nilai kewibawaa jika putusan tersebut memiliki rasa kemanusiaan yang tinggi dan merefleksikan rasa keadilan hukum masyarakat, sehingga untuk itulah diharapkan hakim mempunyai otak yang cerdas dan disertai dengan hati nurani yang bersih.

Salah satu tugas seorang hakim dalam peradilan pidana adalah untuk memutuskan apakah seseorang bersalah atau tidak, Peradilan pidana dilakukan dengan prosedur yang tertuang dalam peraturan-perundang-undangan yang mencakup semua batasbatas konstitusional dan berakhir pada proses pemeriksaan di pengadilan. ${ }^{8}$

Pada Akhirnya dalam proses pemeriksaan terdakwa di pengadilan kemandirian dan kebebasan hakim memutuskan terdakwa bersalah ataukah tidak bersalah dipengaruhi aspek profesionalitas dan integritasnya dalam menjalankan tugas yudisialnya hal ini dapat dipahami karena tujuan dari lembaga peradilan di Indonesia adalah untuk menegakkan hukum demi

${ }^{7}$ Rifai, Ahmad. Penemuan Hukum oleh Hakim dalam persfektif hukum progresif, Sinar Grafika, Jakarta, 2014, hal. 4.

${ }^{8}$ Prasetyo, Teguh. Kemandirian dan kebebasan hakim memutus perkara Pidana, Nusa Media, Bandung, 2015, hal.163. 
keadilan, baik bagi Individu maupun bagi masyarakat, bangsa dan Negara serta keadilan demi Tuhan Yang Maha Esa.

Penerapan Pasal 185 huruf ayat 6 huruf (d) KUHAP telah Memberikan Perlindungan hukum terhadap Terdakwa dalam kaitan Keterangan Saksi yang Tidak Dapat Dipercaya.

Penerapan peraturan yang memberikan perlindungan hukum pada terdakwa dalam kaitanya dengan keterangan saksi yang tidak dapat dipercaya secara tegas dapat dilihat dalam Undangundang Republik Indonesia Nomor 8 tahun 1981 tentang KUHAP yaitu dalam Pasal 185 ayat 6 KUHAP. Ketentuan-ketentuan tersebut adalah untuk mengingatkan hakim agar memperhatikan keterangan saksi secara bebas, jujur, dan objektif.

Keterangan saksi sebagaimana diuraikan dalam rumusan Pasal 185 ayat 6 KUHAP secara rinci mengatur :

1. Keterangan saksi sebagai alat bukti ialah apa yang saksi nyatakan didepan sidang pengadilan.

2. Keterangan seorang saksi saja tidak cukup membuktikan bahwa terdakwa bersalah terhadap perbuatan yang didakwakan kepadanya

3. Ketentuan sebagaimana yang dimaksud dalam ayat (2) tidak berlaku apabila tidak disertai dengan suatu alat bukti yang sah lainnya.

4. Keterangan beberapa saksi yang berdiri sendiri-sendiri tentang suatu kejadian atau keadaan dapat digunakan sebagai suatu alat bukti yang sah, apabila keterangan saksi itu ada hubungannya satu dengan yang lain sedemikian rupa sehingga dapat membenarkan adanya suatu kejadian atau keadaan tertentu. 
5. Baik pendapat maupun rekaan, yang diperoleh dari hasil pemikiran saja bukan merupakan keterangan saksi.

6. Dalam menilai kebenaran keterangan seorang saksi, hakim harus dengan sungguh-sungguh memperhatikan:

a) Persesuaian antara keterangan saksi 1 dengan yang lain.

b) Persesuaian antara keterangan saksi dengan alat bukti lain.

c) Alasan yang mungkin yang dipergunakan oleh saksi untuk memberi keterangan yang tertentu.

d) Cara hidup dan kesusilaan saksi dan segala sesuatu yang pada umumnya dapat mempengaruhi dapat tidaknya keterangan itu dipercaya.

e) Keterangan dari saksi yang tidak disumpah meskipun sesuai dengan yang lain tidak merupakan alat bukti, namun apabila keterangan itu sesuai dengan keterangan dari saksi yang disumpah, dapat dipergunakan sebagai tambahan alat bukti sah yang lain.

Rumusan Pasal 185 ayat 6 huruf (d) KUHAP disebutkan dalam menilai kebenaran keterangan seorang saksi hakim harus sungguh-sungguh memperhatikan cara hidup dan kesusilaan seorang saksi serta segala sesuatu yang pada umumnya dapat mempengaruhi dapat tidaknya keterangan itu dipercaya. Sebagaimana telah penulis uraikan sebelumnya cara hidup dan kesusilaan saksi merupakan Persoalan moralitas, ini berarti mengharuskan hakim masuk dalam Penilaian Baik dan buruknya cara hidup dan kesusilaan saksi sebelum menilai kebenaran keterangan saksi.

Merujuk pada teori perlindungan hukum yang dikemukakan oleh Sudikno Mertokusumo yang intinya 
menyatakan dalam fungsinya sebagai perlindungan kepentingan manusia hukum mempunyai tujuan. Hukum mempunyai sasaran yang hendak dicapai. Adapun tujuan pokok hukum adalah menciptakan tatanan masyarakat yang tertib, menciptakan ketertiban dan keseimbangan. Dengan tercapainya ketertiban dalam masyarakat diharapkan kepentingan manusia akan dilindungi, dalam mencapai tujuanya itu hukum bertugas membagi hak dan kewajiban antar perorangan di dalam masyarakat, membagi wewenang dan mengatur cara memecahkan masalah hukum serta memelihara kepastian hukum.

Menurut pendapat Penulis Ada tiga hal yang dapat dianalisis dari Pandangan Sudikno Mertokusumo sehubungan perlindungan terdakwa dari keterangan saksi yang tidak dapat dipercaya yang mengharuskan hakim masuk dalam Penilaian Baik dan buruknya cara hidup dan kesusilaan saksi sebelum menilai kebenaran keterangan saksi, yaitu meliputi fungsi hukum adalah untuk melindungi kepentingan manusia dalam hal ini Terdakwa dan tujuan hukum adalah menciptakan tatanan masyarakat yang tertib dan berkeseimbangan serta tugas hukum yang utama adalah membagi hak dan kewajiban antar perorangan dalam masyarakat, membagi wewenang, mengatur cara memecahkan masalah hukum dan memelihara kepastian hukum.

Dalam Tindak Pidana Pemalsuan uang keterangan saksi yang pada intinya menyatakan bahwa saksi memiliki kemampuan untuk melakukan penarikan uang seseorang yang dipinjam oleh orang lain secara gaib dengan melalui ritual tertentu padahal kemampuan untuk mendatangkan uang secara gaib berada pada areal diluar jangkauan panca indra manusia, akibat kemampuan tersebut tidak dapat diterima oleh akal sehat, kemudian jika 
memang betul kemampuan tersebut dimiliki oleh saksi maka untuk memenuhi segala kebutuhannya saksi tidak perlu bekerja dan menawarkan jasa kepada orang lain sebab bukankah saksi dengan kemampuannya dapat mendatangkan uang secara gaib.

Hakim berpendapat jika uang yang dihasilkan melalui cara tertentu adalah uang asli maka hal tersebut tidak masuk akal sebab jika saja saksi dapat menghasilkan uang asli tanpa diketahui oleh orang lain tidak perlu saksi melibatkan orang lain untuk mendapatkan uang, telah cukup apabila saksi melakukan sendiri untuk memenuhi segala kebutuhannya tanpa harus berbagi dengan orang lain, dan bila uang yang dihasilkan tersebut adalah uang asli tidak mungkin uang tersebut diserahkan kepada terdakwa sebab hal tersebut hanya akan mendatangkan kerugian yang besar tanpa adanya keuntungan bagi saksi dan hakim berpendapat bahwa uang yang dihasilkan melalui ritual tersebut adalah uang palsu, ritual yang dilakukan oleh saksi hanyalah kedok bahwa ia dengan ritual tersebut dapat menghasilkan atau menarik piutang seseorang dari yang berhutang secara gaib.

Pasal 185 ayat 6 huruf (d) KUHAP mengingatkan hakim agar memperhatikan keterangan saksi secara bebas, jujur, dan objektif, dan KUHAP telah menjabarkan hal ini dalam asas ( Presumption of innoncence) yaitu Perlakuan yang sama atas diri setiap orang di muka hukum dengan tidak mengadakan perbedaan perlakukan; Setiap orang yang disangka, ditangkap, ditahan, dituntut, dan atau dihadapkan di muka sidang pengadilan, wajib dianggap tidak bersalah sampai adanya putusan pengadilan yang menyatakan kesalahannya dan memperoleh kekuatan hukum tetap. Menurut Hunir Fuady Sylvia Laura dalam bukunya Hak Asasi Tersangka Pidana, dokrin praduga tidak bersalah ini juga 
merupakan salah satu unsur terpenting dari prinsip pelaksanaan hukum yang adil (due process). 9

Menurut pendapat Penulis keadilan menjadi landasan utama yang harus diwujudkan melalui hukum yang ada, Aristoteles menegaskan bahwa keadilan adalah inti dari hukum. keadilan dipahami dalam pengertian kesamaan, namun bukan kesamarataan. Membedakan hak persamaanya sesuai dengan hak proposional. Kesamaan proposional memberi tiap orang apa yang menjadi haknya sesuai dengan kemampuan dan prestasi yang telah dilakukanya. Arietoteles juga membedakan dua macam keadilan, keadilan "distributief" dan keadilan "commutatief". Keadilan distributief ialah keadilan yang memberikan kepada tiap orang porsi menurut pretasinya. Keadilan commutatief memberikan sama banyaknya kepada setiap orang tanpa membeda-bedakan prestasinya.

Patut dicermati pula dalam menilai keterangan saksi sebagaimana dimaksud dalam pasal 185 ayat (6) KUHAP, seorang Hakim hendaknya sungguh-sungguh memperhatikan cara hidup dan kesusilaan saksi, seorang saksi yang misalnya terbiasa melakukan perdukunan uang, menggandakan uang mata uang dan seterusnya. Padahal dimanapun semua orang pastia tahu ( merupakan hal yang diketahui umum perbuatan tersebut menyesatkan dan jelas merupakan penipuan dan seterusnya), padahal keterangan saksi bisa dijadikan sebagai alat bukti yang menguatkan bukti terdakwa bersalah telah melakukan tindak pidana.

Begitu pula dengan keterangan seorang saksi yang apabila dihubungan dengan Pasal 185 ayat (6) huruf d, memiliki cara

9 Fuady,Munir dan Sylvia Laura L.Fuady, Hak Asasi Tersangka Pidana, Prenada Media Group, 2015, hal.234. 
hidup dan kesusilaan yang tidak baik yaitu saksi membeli minuman keras dengan uang yang bukan miliknya dan memiliki kebiasaan yang suka meminum minuman keras.

Upaya yang Dilakukan Hakim untuk Melindungi hak Terdakwa dari Keterangan Saksi yang Tidak Dapat Dipercaya

Salah satu bentuk penjabaran dari asas praduga tidak bersalah (presumption of innocence) dapat dilihat dalam Pasal 66 KUHAP yang menegaskan Tersangka/terdakwa tidak dibebani kewajiban pembuktian. Dalam hukum acara pidana dikenal asas siapa yang menyangka/mendakwa diwajibkan membuktikan kebenaran dari dakwaannya, karena dalam proses pemeriksaan perkara pidana yang membuat, menyampaikan dakwaan adalah jaksa penuntut umum, maka yang dibebani kewajiban untuk membuktikan kesalahan terdakwa adalah jaksa PU (burden of proof is always on the prosecutor).

Upaya hakim dalam melindungi hak-hak tersangka dari keterangan saksi yang tidak dapat dipercaya dapat dilihat pada rumusan Pasal 185 KUHAP ayat 6 huruf (d), dari rumusan Pasal tersebut dapat dijelaskan adanya Perbuatan / tindakan Hakim menilai kebenaran keterangan saksi dalam persidangan dengan kesungguhan memperhatikan cara hidup dan kesusilaan saksi agar dapat diperoleh nilai kebenaran kesaksian yang betul-betul sesuai dengan fakta yang dapat diterima akal sehat dan moral.

Menurut pendapat Penulis tidak dapat dipercaya atau dapat dipercaya Keterangan saksi sangat tergantung dengan Cara Hidup dan Kesusilaan saksi dan dipengaruhi oleh sikap batin seorang saksi yang dapat berbicara tentang kehendak baik (gagasan actual dan jelas), dan keterangan saksi yang tidak dapat 
dipercaya merupakan kehendak jahat jika perbuatan kehendak diikat oleh gagasan yang tidak jelas.

Aspek hukum moral dari keterangan saksi yang benar dan dapat dipercaya selalu di dasarkan pada naluri, intuisi, dan kesusilaan manusia yang selalu mengatakan tidak ada sesuatu yang lebih tinggi dari pada suatu perbuatan yang dilakukan karena kehendak baik terlepas dari akibat-akibatnya.

Kejujuran adalah inti penilaian dari kebenaran keterangan saksi, perwujudan kejujuran adalah sebagai konsekuensi dari seorang saksi sebagai manusia, hal ini berarti kelalaian seorang saksi melaksanakanya merupakan perbuatan yang tidak manusiawi. Penilaian hakim dalam wilayah moral saksi menyangkut kepercayaan, niat, motivasi, keputusan, dan konsepkonsep moral dalam diri seorang saksi.

Menganalisa aspek Keadilan Moral (Moral Justice) dan Moral Hukum (Legal Justice) Hakim dalam menilai kebenaran keterangan saksi di hubungkan dengan Pasal 185 KUHAP ayat (6) huruf (d) seorang hakim tidak begitu saja percaya atas faktafakta hukum yang disampaikan saksi-saksi dalam persidangaan khususnya saksi yang memiliki cara hidup dan kesusilaan yang tidak baik yaituse bagai contoh diatas seorang saksi yang mengaku dapat menggandakan uang secara gaib padahal hal tersebut tidak masuk akal sehat manusia biasa dan saksi yang memiliki cara hidup tidak baik yaitu suka bermabuk-mabukan/ minum minuman keras

\section{KESIMPULAN}

1) Ketentuan Pasal 185 Ayat 6 Huruf (D) Kuhap Telah Memberikan Perlindungan Hukum Terhadap Terdakwa 
Dalam Kaitan Keterangan Saksi Yang Tidak Dapat Dipercaya, Pasal 185 Ayat 6 Huruf (D) Kuhap Mengingatkan Hakim Agar Memperhatikan Keterangan Saksi Secara Bebas, Jujur, Dan Objektif.

2) Rumusan Pasal 185 Kuhap Ayat (6) Huruf (D) Memberikan Patokan/Rambu Pada Hakim Agar Memperhatikan Kesusilaan Dan Cara Hidup Saksi Pada Saat Seorang Saksi Memberikan Keterangan Tentang Apa Yang Saksi Lihat/ Saksikan, Saksi Dengar Dan Ketahui Tentang Suatu Fakta Didepan Persidangan Agar Nantinya Hakim Dapat Memberikan Putusan Yang Adil Bagi Terdakwa.

3) Prakek Peradilan Pidana Saat Ini Masih Banyak Mengabaikan Aspek Perlindungan Terdakwa Dari Keterangan Saksi Yang Tidak Dipercaya, Begitu Pula Dalam Karya Tulis Ilmiah Belum Banyak Membahas Topik Perlindungan Terdakwa Dari Keterangan Saksi Yang Tidak Dipercaya.

4) Perlu Kajian Lebih Mendalam Terhadap Aspek Teoritis, Yuridis, Dan Normatif Terhadap Perlindungan Terdakwa Dari Keterangan Saksi Yang Tidak Dipercaya.

\section{DAFTAR PUSTAKA}

Alfitra, Hukum Pembuktian dalam beracara Pidana,Perdata dan korupsi di Indonesia, Depok, Raih Asa sukses, 2011.

Ahmad Rifai, Penemuan Hukum oleh Hakim dalam persfektif hukum progresif, Sinar Grafika, Jakarta, 2014.

Chazawi Adami, Ardi Ferdian, Tindak Pidana Pemalsuan, PT. RajaGrafindo Persada, Jakarta, 2014

Harris Soche,Supremasi hukum dan prinsip demokrasi di Indonesia, PT.Hanindita, Jogjakarta,1985.

Kuffal HMA, Penerapan KUHAP dalam praktik Hukum, UMM Press,Malang, 2011. 
Fuady Munir dan Sylvia Laura L.Fuady,Hak Asasi Tersangka Pidana,Prenada Media Group,2015.

Lubis,Sofyan. Hak tersangka sebelum pemeriksaan, Pustaka Yustisia, Yogyakrta,2010.

M.Hadjon, Phillipus. Perlindungan hukum bagi Rakyat Indonesia, PT.Bina Ilmu, Surabaya, 1987

Mahrus Ali, asas, Teori dan Praktek Hukum Pidana Korupsi, UII Press,Yogyakarta, 2013.

Jonaedi Efendi, Suhartono. Panduan Praktis Bila Anda Menghadapi Perkara Pidana Mulai proses penyelidikan hingga persidangan, Jakarta, Prenadamedia Group, 2013.

Prasetyo,Teguh. Kemandirian dan kebebasan hakim memutus perkara Pidana, Nusa Media, Bandung, 2015.

Salim HS dan Nurbaini,E.S.,Penerapan teori hukum Hukum pada Penelitian Tesis dan Disertasi, PT.Raja Grafindo Persada, Jakarta, 2014.

Satochid Kartanegara, Hukum Pidana, Bagian satu, hukum Pidana Bagian Dua, Balai Lektur Mahasiswa, Jakarta, tanpa tahun.

Titus et.al., Persoalan-persoalan Filsafat,Terjemahan, H.M.Rasjidi, Bulan Bintang, Jakarta, 1984.

\section{PERATURAN PERUNDANG-UNDANGAN}

KUHAP dan KUHP, SL Media, Tangerang Selatan.

Undang-Undang Republik Indonesia No.18 Tahun 2003 tentang Advokat, SL.Media,Tangerang Selatan.

Undang-undang Republik Indonesia No.39 tahun 1999 Tentang Hak Asasi Manusia.

Undang-Undang Perlindungan saksi \& Korban Undang-Undang RI Nomor 31 Tahun 2014 Tentang Perubahan atas Undangundang nomor 13 Tahun 2006 Tentang Perlindungan saksi dan Korban, Pustaka Mahardika, Jogjakarta, 2015.

Undang-Undang Republik Indonesia tentang Mahkamah Agung,Pengadilan Tipikor, Kekuasaan Kehakiman, Peradilan 
Umum ,Peradilan Agama, beserta penjelasanya, PT.Grafitri, Bandung, 
